\title{
Calculation of Reactive-Evaporation Rates of Chromia
}

\section{Gordon R. Holcomb ${ }^{1}$}

(1) Materials Performance Division, National Energy Technology Laboratory, Albany, OR, USA, Gordon.Holcomb@netl.doe.gov

\begin{abstract}
A methodology is developed to calculate $\mathrm{Cr}$ evaporation rates from $\mathrm{Cr}_{2} \mathrm{O}_{3}$ with a flat planar geometry. Variables include temperature, total pressure, gas velocity, and gas composition. The methodology was applied to solid oxide fuel cell conditions for metallic interconnects and to advanced steam turbines conditions. The high velocities and pressures of the advanced steam turbine led to evaporation predictions as high as $5.18 \times 10^{-8} \mathrm{~kg} / \mathrm{m}^{2} / \mathrm{s}$ of $\mathrm{CrO}_{2}(\mathrm{OH})_{2}(\mathrm{~g})$ at $760^{\circ} \mathrm{C}$ and $34.5 \mathrm{MPa}$. This is equivalent to $0.080 \mathrm{~mm}$ per year of solid Cr loss. Chromium evaporation is expected to be an important oxidation mechanism with the types of nickel-base alloys proposed for use above $650^{\circ} \mathrm{C}$ in advanced steam boilers and turbines. It is shown that laboratory experiments, with much lower steam velocities and usually much lower total pressure than found in advanced steam turbines, would best reproduce chromium evaporation behavior with atmospheres that approach either $\mathrm{O}_{2}+\mathrm{H}_{2} \mathrm{O}$ or $\mathrm{Air}+\mathrm{H}_{2} \mathrm{O}$ with $57 \% \mathrm{H}_{2} \mathrm{O}$.
\end{abstract}

Key Words: oxidation; modeling; nickel alloys; stainless steels; chromia evaporation, chromia volatilization.

\section{Introduction}

The oxidation of alloys protected by the formation of $\mathrm{Cr}_{2} \mathrm{O}_{3}$ (chromia formers) can undergo scale loss due to reactive evaporation of chromium containing gas species. Water vapor increases the evaporation loss by allowing the formation of $\mathrm{CrO}_{2}(\mathrm{OH})_{2}(\mathrm{~g})$, which for the same conditions has a higher vapor pressure than $\mathrm{CrO}_{3}(\mathrm{~g}) . \mathrm{CrO}_{3}(\mathrm{~g})$ is the predominate $\mathrm{Cr}$ gas specie in dry air or oxygen. This degradation mechanism is of great importance on the cathode-side of solid oxide fuel cell (SOFC) interconnects, where deposition of $\mathrm{Cr}$ at triple-phase points can degrade the fuel cell. ${ }^{1-4}$ It may also be important as a long-term degradation mechanism in the steam side of advanced coal power plants.

A generalized reaction equation for $\mathrm{Cr}$ evaporation from $\mathrm{Cr}_{2} \mathrm{O}_{3}$ is

$1 / 2 \mathrm{Cr}_{2} \mathrm{O}_{3}(\mathrm{~s})+\mathrm{nH}_{2} \mathrm{O}(\mathrm{g})+\mathrm{mO}_{2}(\mathrm{~g})=\mathrm{CrO}_{1.5+\mathrm{n}+2 \mathrm{~m}} \mathrm{H}_{2 \mathrm{n}}(\mathrm{g})$

For $\mathrm{CrO}_{2}(\mathrm{OH})_{2}(\mathrm{~g}), \mathrm{n}=1$ and $\mathrm{m}=3 / 4$ so Eq. 1 becomes:

$1 / 2 \mathrm{Cr}_{2} \mathrm{O}_{3}(\mathrm{~s})+\mathrm{H}_{2} \mathrm{O}(\mathrm{g})+3 / 4 \mathrm{O}_{2}(\mathrm{~g})=\mathrm{CrO}_{2}(\mathrm{OH})_{2}(\mathrm{~g})$

Evaporation can change the overall oxidation kinetics from parabolic behavior to linear kinetics or even to breakaway oxidation. Linear kinetics can arise after scale growth from oxidation, which decreases with increasing scale thickness, matches the scale loss from reactive evaporation. The change in scale thickness, $\mathrm{x}$, with time, $\mathrm{t}$, can be described in terms of the parabolic rate constant, $\mathrm{k}_{\mathrm{p}}$, and the linear reactive evaporation rate, $\mathrm{k}_{\mathrm{e}}$, as:

$\frac{d x}{d t}=\frac{k_{p}}{x}-k_{e}$

At long times or high reactive evaporation rates, a limiting scale thickness, $\mathrm{x}_{\mathrm{L}}$, arises that is given by:

$x_{L}=\frac{k_{p}}{k_{e}}$ 
In this case metal loss rates are linear, but still involve diffusion through a protective scale. Rapid metal loss can occur when reactive evaporation of $\mathrm{Cr}$ depletes the scale (and sometimes the substrate metal) of $\mathrm{Cr}^{5-6}$

Decreased $\mathrm{Cr}$ in the scale or metal can lead to the formation of less protective oxides, such as $\mathrm{Fe}-\mathrm{Cr}$ oxides in Fe-Cr base alloys. Unprotective scales can lead to rapid metal loss, or "break-away" oxidation.

A methodology for calculating evaporation rates in a variety of environments is presented, including those found in a SOFC and in a high pressure steam turbine. Experimental results will be used to validate the methodology.

\section{Methodology}

\section{Evaporation}

One way to determine evaporation rates is to assume that volatility is limited by the transport of the volatile specie through a boundary layer in the gas phase. For flat plate geometry with laminar flow, the evaporation rate can be calculated by Eq. $5:^{7-8}$

$k_{e}\left(\frac{k g}{m^{2} s}\right)=0.664 R e^{0.5} S c^{0.343} \frac{D_{A B} \rho}{L}$

Where Re and Sc are the dimensionless Reynolds and Schmidt numbers, $\mathrm{D}_{\mathrm{AB}}$ is the gaseous diffusion coefficient between the Cr gas specie and the solvent gas $\left(\mathrm{m}^{2} / \mathrm{s}\right), \rho$ is the density $\left(\mathrm{kg} / \mathrm{m}^{3}\right)$ of the evaporative specie in the gas, and $\mathrm{L}$ is the length $(\mathrm{m})$ in the flow direction of the flat plate. Equation 5 is valid for $\mathrm{Sc}$ numbers between 0.6 and $50 .^{7}$ Assuming ideal gas behavior and a reaction described by Eq. 1, this can be expanded to:

$k_{e}\left(\frac{\mathrm{kg}}{\mathrm{m}^{2} \mathrm{~s}}\right)=0.664 \operatorname{Re}^{0.5} \mathrm{Sc}^{0.343} \frac{D_{A B} M_{i}}{L R_{1} T} P_{\mathrm{CrO}_{1.5+n+2 m} \mathrm{H}_{2 n}}$

Where $P_{i}$ is the partial pressure of gas specie $i(a t m), M_{i}$ is the molecular mass $(\mathrm{kg} / \mathrm{g}-\mathrm{mol})$ of gas specie $i$ (in this case $i$ is the Cr-containing gas specie), $R_{1}$ is the gas constant $\left(8.20594 \times 10^{-5} \mathrm{~m}^{3} \mathrm{~atm} / \mathrm{K}\right.$ g-mol), and $T$ is the absolute temperature $(\mathrm{K})$. The dimensionless Reynolds and Schmidt numbers are defined as:

$R e=\frac{\rho_{s} u L}{\eta}$

Sc $=\frac{\eta}{\rho_{s} D_{A B}}$

Where $\rho_{\mathrm{s}}$ is the density of the solvent gas $\left(\mathrm{kg} / \mathrm{m}^{3}\right), \eta$ is the absolute viscosity $(\mathrm{kg} / \mathrm{m} / \mathrm{s})$ and $\mathrm{u}$ is the gas velocity $(\mathrm{m} / \mathrm{s})$.

For turbulent flow $\left(\operatorname{Re}>5 \times 10^{5}\right)$, the equation equivalent to Eq. 6 is: ${ }^{7}$

$k_{e}\left(\frac{\mathrm{kg}}{\mathrm{m}^{2} \mathrm{~s}}\right)=0.0592 \operatorname{Re}^{4 / 5} \mathrm{Sc}^{1 / 3} \frac{D_{A B} M_{i}}{L R_{1} T} P_{\mathrm{CrO}_{1.5+n+2 m} H_{2 n}}$

In the case of reaction in Eq. 2, the last term in Eqs. 6 and $9\left(\mathrm{P}_{\mathrm{CrO} 2(\mathrm{OH}) 2}\right)$ is found by:

$P_{\mathrm{CrO}_{2}(\mathrm{OH})_{2}}(\mathrm{~atm})=a_{\mathrm{Cr}_{2} \mathrm{O}_{3}}^{1 / 2} P_{\mathrm{H}_{2} \mathrm{O}} P_{\mathrm{O}_{2}}^{3 / 4} \exp \left(\frac{\Delta G_{2}^{\circ}}{R_{2} \mathrm{~T}}\right)$ 
Where $\mathrm{a}_{\mathrm{Cr} 2 \mathrm{O} 3}$ is the activity $\mathrm{Cr}_{2} \mathrm{O}_{3}, \Delta \mathrm{G}_{2}{ }^{\circ}$ is the Gibbs energy of Eq. $2(\mathrm{~J} / \mathrm{g}-\mathrm{mol})$, and $\mathrm{R}_{2}$ is the gas constant (8.3146 J/K g-mol).

Each of the parameters in Eqs. (6-10) that require additional commentary will be described.

\section{Diffusion Coefficient, $\mathbf{D}_{\mathrm{AB}}$}

Estimation of the diffusion coefficient, $\mathrm{D}_{\mathrm{AB}}$, between the $\mathrm{Cr}$ gas species and the solvent gas is the most tenuous of the parameters. Tucker and Nelken ${ }^{9}$ compared several different methods for estimation of $\mathrm{D}_{\mathrm{AB}}$ and of two recommended choices, the one developed by Fuller et al. ${ }^{10}$ is used here because it contains fewer parameters that themselves need to be estimated. After conversion to SI units (but with atm for pressure), the estimation equation is:

$D_{A B}=\frac{\left(3.162 \times 10^{-9}\right) T^{1.75}}{P_{T}\left(\mathrm{v}_{A}^{1 / 3}+\mathrm{v}_{B}^{1 / 3}\right)^{2}} \sqrt{\frac{1}{M_{A}}+\frac{1}{M_{B}}}$

Here $v_{i}$ is the diffusion volume of species $\mathrm{i}\left(\mathrm{m}^{3} / \mathrm{mol}\right)$. Diffusion volumes, as given by Fuller et al. ${ }^{10}$, were from a fit of Eq. 11 with an extensive list of diffusion data measurements of various A-B pairs. Table 1 lists $\mathrm{M}_{\mathrm{i}}$ and $\mathrm{v}_{\mathrm{i}}$ for several of gas species and gas mixtures. Diffusion volumes of $\mathrm{Cr}$ gas species are not available and so were estimated based on a molecule with a radius of $1.6 \times 10^{-10} \mathrm{~m}$, then converted to molar volume. The value of $1.6 \times 10^{-10} \mathrm{~m}$ comes from a density functional theory estimation of the length of a Cr-O bond in CrO. ${ }^{11}$ The values of $\mathrm{v}_{\mathrm{i}}$ for the mixtures other than air were based on a weighted average of the component $\mathrm{v}_{\mathrm{i}}$ values.

An additional consideration for supercritical steam turbine environments is that $\mathrm{D}_{\mathrm{AB}}$ can diverge from the inverse pressure relationship of Eq. 11 at high pressures. ${ }^{12}$ As an approximation, Fig. 1 can be used to estimate the reduction in $\mathrm{D}_{\mathrm{AB}}$ at high pressures. In Fig. $1, \mathrm{PD} /(\mathrm{PD})^{\circ}$ is the ratio of the pressure-diffusivity product at pressure $\mathrm{P}$ to the pressure-diffusivity product at low pressure (both at the same $\mathrm{T}$ ). $\mathrm{T}_{\mathrm{r}}$ and $\mathrm{P}_{\mathrm{r}}$ are the reduced temperature and pressure and are equal to $\mathrm{T} / \mathrm{T}_{\text {critical }}$ and $\mathrm{P} / \mathrm{P}_{\text {critical }}$. For water $\mathrm{T}_{\text {critical }}$ is $647.25 \mathrm{~K}$ and $\mathrm{P}_{\text {critical }}$ is $218.25 \mathrm{~atm}$. As an example, consider the conditions of $760^{\circ} \mathrm{C}$ and $340 \mathrm{~atm}$. In this case $\mathrm{T}_{\mathrm{r}}$ is 1.60 and $\mathrm{P}_{\mathrm{r}}$ is 1.56 , which gives a $\mathrm{PD} /(\mathrm{PD})^{\circ}$ value of 0.88 . So the value of $\mathrm{D}_{\mathrm{AB}}$ obtained from $\mathrm{Eq} .11$ is adjusted by multiplying it by 0.88 . This reduction factor is an approximation because this figure is a part of a diagram that was developed for self-diffusivity using Enskog kinetic theory and fragmentary data. ${ }^{13}$

\section{Absolute Viscosity, $\eta$}

The absolute viscosity of non-polar gases, for example $\mathrm{O}_{2}, \mathrm{~N}_{2}$, Ar, and air, can be calculated from the following equation based on the Lennard-Jones potential: ${ }^{7-8}$

$\eta=8.44 \times 10^{-25} \frac{\sqrt{M T}}{\sigma^{2} \Omega_{\eta}}$

Where $\eta$ is in $\mathrm{kg} / \mathrm{m} / \mathrm{s}, \sigma$ is a characteristic diameter of the molecule in $\mathrm{m}$, and $\Omega_{\eta}$ is the dimensionless collision integral, which is a function of $\kappa_{B} T / \varepsilon$. The term $\kappa_{B} T / \varepsilon$ is a viscosity function based on the Lennard-Jones potential, where $\kappa_{\mathrm{B}}$ is the Boltzmann constant and $-\varepsilon$ is the minimum energy of the LennardJones potential function. Values of $\sigma$ and $\varepsilon / \kappa_{B}$ are given in Table $2 .^{7-8}$ The value of $\Omega_{\eta}$ can then be found from Table $3 .^{7-8}$

The absolute viscosity of water, in the temperature range of interest, can be found using Eq. 13, which was obtained from linear portions of absolute viscosity curves as functions of temperature and pressure. ${ }^{14}$ Equation 13 is for the temperature range $811 \mathrm{~K}-1089 \mathrm{~K}$ and pressures up to $340 \mathrm{~atm}$ where the linear fit has a correlation coefficient $\left(\mathrm{R}^{2}\right)$ of 0.994 . Absolute viscosities for temperatures below $811 \mathrm{~K}$, nearer to the critical point of water, are decidedly non-linear and Eq. 13 should not be used.

$\eta=3.701 \times 10^{-8}+3.080 \times 10^{-7} T+1.160 \times 10^{-8} P_{T}$ 
For gas mixtures, the absolute viscosity of each component gas was combined using Eqs. 14-15, which is the semiempirical formulation of Wilke: ${ }^{7-8,15}$

$\eta_{\text {mix }}=\sum_{i=1}^{n} \frac{x_{i} \eta_{i}}{\sum_{j=1}^{n} x_{j} \Phi_{i j}}$
$\Phi_{i j}=\frac{1}{\sqrt{8}}\left(1+\frac{M_{i}}{M_{j}}\right)^{-1 / 2}\left[1+\left(\frac{\eta_{i}}{\eta_{j}}\right)^{1 / 2}\left(\frac{M_{j}}{M_{i}}\right)^{1 / 4}\right]^{2}$

\section{Solvent Gas Density, $\rho_{\mathrm{s}}$}

The density of the solvent gas is found by assuming ideal gas behavior, which allows Eq. 16:

$\rho_{s}=\frac{P_{T} M_{\text {Ave }}}{R_{1} T}$

Where $\mathrm{M}_{\mathrm{Ave}}$ is the average molecular weight of the solvent gas mixture.

\section{Gibbs Energy, $\Delta G$}

The two primary $\mathrm{Cr}$ gas species for reactive evaporation are $\mathrm{CrO}_{3}(\mathrm{~g})$ in either dry conditions or moist conditions at higher temperatures, and $\mathrm{CrO}_{2}(\mathrm{OH})_{2}(\mathrm{~g})$ in moist conditions at most of the temperatures of interest here. Equation 2 describes the evaporation reaction for $\mathrm{CrO}_{2}(\mathrm{OH})_{2}(\mathrm{~g})$. It is necessary to know the Gibbs energy of formation for each of the products and reactants in Eq. 2 to obtain the $\Delta \mathrm{G}$ of the reaction used in Eq 10. The general form for $\Delta \mathrm{G}$ of Eq. 1 is given by:

$\Delta \mathrm{G}_{1}=-\mathrm{R}_{2} \mathrm{~T} \ln \frac{\mathrm{P}_{\mathrm{CrO}_{1.5+\mathrm{n}+2 \mathrm{~m}} \mathrm{H}_{2 \mathrm{n}}}}{\mathrm{a}_{\mathrm{Cr}_{2} \mathrm{O}_{3}}^{1 / 2} \mathrm{P}_{\mathrm{O}_{2}}^{m} \mathrm{P}_{\mathrm{H}_{2} \mathrm{O}}^{\mathrm{n}}}$

The $\Delta \mathrm{G}_{\mathrm{f}}$ for $\mathrm{CrO}_{2}(\mathrm{OH})_{2}(\mathrm{~g})$ is not well established. Opila ${ }^{16}$ has reviewed the literature and has found that using data based on Glusko ${ }^{17}$ results in much lower calculated partial pressures of $\mathrm{CrO}_{2}(\mathrm{OH})_{2}(\mathrm{~g})$ than using data based on Ebbinghaus. ${ }^{18}$ Glusko ${ }^{17}$ is the source of $\mathrm{CrO}_{2}(\mathrm{OH})_{2}(\mathrm{~g})$ data for the ITVAN ${ }^{19}$ and $\mathrm{HSC}^{20}$ thermodynamics programs. The experimental data of Gindorf et al. ${ }^{21}$ lie between that predicted by Glusko ${ }^{17}$ and Ebbinghaus ${ }^{18}$ (in terms of $\log \mathrm{P}_{\mathrm{CrO}(\mathrm{OH}) 2}$ ). The Glusko ${ }^{17}$ and Ebbinghaus ${ }^{18}$ data sources form lower and upper bounds for predicting evaporation losses. Ebbinghaus ${ }^{18}$ used estimates of molecular parameters to formulate thermodynamic information. Gindorf ${ }^{21}$ used transpiration experiments to measure the partial pressure of $\mathrm{CrO}_{2}(\mathrm{OH})_{2}(\mathrm{~g})$. It is unclear ${ }^{16}$ how the Glusko ${ }^{17}$ data was generated. Table 4 shows $\Delta \mathrm{G}_{\mathrm{f}}$ values for compounds and species of interest.

The partial pressures of $\mathrm{CrO}_{3}(\mathrm{~g})$ and $\mathrm{CrO}_{2}(\mathrm{OH})_{2}(\mathrm{~g})$ over pure $\mathrm{Cr}_{2} \mathrm{O}_{3}$ (activity of 1 ) were found for conditions of atmospheric pressure, $\mathrm{P}_{\mathrm{O} 2}=0.20$, and $\mathrm{P}_{\mathrm{H} 2 \mathrm{O}}=0.03$ (air plus $3 \% \mathrm{H}_{2} \mathrm{O}$ ) and are shown in Fig. 2a. Figures $2 \mathrm{~b}$ and $2 \mathrm{c}$ also show partial pressures of $\mathrm{CrO}_{3}(\mathrm{~g})$ and $\mathrm{CrO}_{2}(\mathrm{OH})_{2}(\mathrm{~g})$ over pure $\mathrm{Cr}_{2} \mathrm{O}_{3}$, but in these cases for $\mathrm{H}_{2} \mathrm{O}$ with $180 \mathrm{ppb}$ dissolved $\mathrm{O}_{2}$ (DO). Figure $2 \mathrm{~b}$ is at atmospheric pressure and Fig. $2 \mathrm{c}$ is at 300 atm.

Since the formation of $\mathrm{CrO}_{2}(\mathrm{OH})_{2}(\mathrm{~g})$ reduces the total moles of gas, higher pressures increase its partial pressure (Figs. 2b-2c). Conversely the formation of $\mathrm{CrO}_{3}(\mathrm{~g})$ increases the total moles of gas, so higher pressures decrease its partial pressure (Figs. 2b-2c). 


\section{Experimental Comparison}

Experiments best suited to verify the methodology have situations where a steady-state scale thickness (Eq. 4) is quickly established and mass loss due to reactive evaporation of $\mathrm{Cr}_{2} \mathrm{O}_{3}$ can be found from mass change with time measurements. Several such tests are described below. Otherwise it would be necessary to separate the effects from scale growth from oxidation and scale thinning from evaporation by the integration of Eq. 3, from which it can be difficult to obtain reliable $\mathrm{k}_{\mathrm{p}}$ and $\mathrm{k}_{\mathrm{e}}$ values.

Cyclic oxidation experiments on Haynes 230 (UNS NO6230) 22 and Inconel 625 (UNS NO6625) were conducted in air in the presence of steam at atmospheric pressure. The compositions of these alloys are given in Table 5. This was designed to examine the adhesion and spallation behavior of protective oxides. The tests consisted of 1-hour cycles of heating and cooling (55 minutes in the furnace and 5 minutes out of the furnace) in a tube furnace equipped with a programmable slide to raise and lower the samples, Fig. 3. Periodically (between cycles) the samples were removed for mass measurements and then returned for more exposure. The suspension of the samples as shown in Fig. 3 allowed the passage of the gas steam to flow unimpeded across the samples. Water was metered into the bottom of the furnace along with compressed air. Two total gas flow rates were used with rates of $1.9 \times 10^{-3} \mathrm{~m} / \mathrm{s}(38 \%$ water vapor and air, by volume $)$ and $7.6 \times 10^{-3} \mathrm{~m} / \mathrm{s}$ ( $37 \%$ water vapor and air, by volume). The exposure temperature for these tests was $760^{\circ} \mathrm{C}$. There was no evidence of scale spallation during these tests. In similar tests on certain other alloys, for example with TP347HFG, there was evidence of scale spallation from visible scale debris from handling during mass measurements.

Note that the reactive evaporation rates calculated from the preceding methodology are on a $\mathrm{CrO}_{2}(\mathrm{OH})_{2}(\mathrm{~g})$ basis and the experimental mass losses were from chromia scale evaporation and so are on a $\mathrm{Cr}_{2} \mathrm{O}_{3}$ (s) basis. To compare the two rates on the same $\mathrm{Cr}_{2} \mathrm{O}_{3}$ basis, the following conversion was used:

$k_{e}\left[\mathrm{Cr}_{2} \mathrm{O}_{3}\right.$ basis $]=\frac{M_{\mathrm{Cr} 2 \mathrm{O} 3}}{2 \mathrm{M}_{\mathrm{CrO} 2(\mathrm{OH}) 2}} k_{e}\left[\mathrm{CrO}_{2}(\mathrm{OH})_{2}\right.$ basis $]=0.644 k_{e}\left[\mathrm{CrO}_{2}(\mathrm{OH})_{2}\right.$ basis $]$

Results from these tests are shown in Fig. 4 in comparison with predicted slopes from reactive evaporation of $\mathrm{Cr}_{2} \mathrm{O}_{3}(\mathrm{~s})$ to $\mathrm{CrO}_{2}(\mathrm{OH})_{2}(\mathrm{~g})$ using the Gindorf ${ }^{21}$ data for $\mathrm{CrO}_{2}(\mathrm{OH})_{2}(\mathrm{~g})$. The agreement is close, suggesting that the reactive evaporation methodology is validated for this case.

Figure 5 is a backscattered electron micrograph of Haynes 230 (UNS NO6230) after exposure at $760^{\circ} \mathrm{C}$ in moist air for 2000 cycles. It shows a very thin oxide scale, approximately $1 \mu \mathrm{m}$ thick. Aluminum was internally oxidized.

Table 6 shows a comparison of the experimental slopes (after 200 hours for the $1.9 \times 10^{-3} \mathrm{~m} / \mathrm{s}$ data and after 24 hours with the $7.7 \times 10^{-3} \mathrm{~m} / \mathrm{s}$ data) and the predicted reactive evaporation rates using the three sets of $\Delta \mathrm{G}_{\mathrm{f}}$ data for $\mathrm{CrO}_{2}(\mathrm{OH})_{2}(\mathrm{~g})$. The evaporation model results using Gindorf $\Delta \mathrm{G}$ values are in good to excellent agreement with experimental values.

Table 6 also compares experimental results from Asteman et al. ${ }^{7}$ for 304L (UNS S30403, composition in Table 5) at $600^{\circ} \mathrm{C}$ in $10 \% \mathrm{H}_{2} \mathrm{O}$ in $\mathrm{O}_{2}$. In this case evaporation was evident from 72 to 168 hours of exposure. Once again there is good agreement between experiment and evaporation rates calculated using the Gindorf ${ }^{21}$ data for $\mathrm{CrO}_{2}(\mathrm{OH})_{2}(\mathrm{~g})$.

For the applications and experimental designs that follow, the Gindorf ${ }^{21}$ data for $\mathrm{CrO}_{2}(\mathrm{OH})_{2}(\mathrm{~g})$ is used.

Asteman et al. ${ }^{6}$ also showed breakaway oxidation for $304 \mathrm{~L}$ at $600^{\circ} \mathrm{C}$ in $40 \% \mathrm{H}_{2} \mathrm{O}$ in $\mathrm{O}_{2}$. For a gas mixture of $\mathrm{H}_{2} \mathrm{O}$ and $\mathrm{O}_{2}$, the equilibrium constant in Eq. 2 can be used to show that the partial pressure of $\mathrm{CrO}_{2}(\mathrm{OH})_{2}(\mathrm{~g})$ is at a maximum with $\mathrm{P}_{\mathrm{H} 2 \mathrm{O}}={ }^{4} /{ }_{7} \mathrm{P}_{\mathrm{O} 2}\left(\sim 57 \% \mathrm{H}_{2} \mathrm{O}\right)$. So increasing the water content in Asteman et al. ${ }^{6}$ from $10 \%$ to $40 \%$ increased the evaporation rate, which led to breakaway oxidation due to a depletion of $\mathrm{Cr}$ in the scale. 


\section{Solid Oxide Fuel Cell Environments}

The environment of the cathode of a SOFC consists of ambient air - thus air containing some fraction of water vapor. For SOFC with metallic interconnects, Cr-gas species from the interconnect can deposit to form $\mathrm{Cr}_{2} \mathrm{O}_{3}$ at the triple points at the porous cathode and electrolyte interface (the triple point refers to locations at the interface where the electrolyte, cathode, and gas phases meet). Cell degradation results from this poisoning of the triple points by $\mathrm{Cr}_{2} \mathrm{O}_{3}$. The methodology of $\mathrm{Cr}$ evaporation using Eq. 6. for laminar gas flow should work well in SOFC environments.

\section{Mitigation}

Some of the efforts to mitigate Cr-evaporation act to reduce the activity of $\mathrm{Cr}_{2} \mathrm{O}_{3}$ in the scale, which reduces the partial pressure of $\mathrm{CrO}_{2}(\mathrm{OH})_{2}(\mathrm{~g})$ as seen through the equilibrium constant in Eq. 17. The formation of $\mathrm{MnCr}_{2} \mathrm{O}_{4}$ spinel should reduce $\mathrm{Cr}$ evaporation by a factor of 55 at $700^{\circ} \mathrm{C}$ and by a factor of 35 at $800^{\circ} \mathrm{C} .^{23}$ In this case the reactive evaporation reaction is:

$1 / 2 \mathrm{MnCr}_{2} \mathrm{O}_{4}(\mathrm{~s})+\mathrm{H}_{2} \mathrm{O}(\mathrm{g})+3 / 4 \mathrm{O}_{2}(\mathrm{~g})=\mathrm{CrO}_{2}(\mathrm{OH})_{2}(\mathrm{~g})+1 / 2 \mathrm{MnO}(\mathrm{s})$

This strategy is inherent in interconnect alloys that contain relatively large amounts of $\mathrm{Mn}$, such as Crofer 22 APU (DIN EN X1CrTiLa22) with 0.3 to $0.8 \mathrm{wt} \% \mathrm{Mn}$ and stainless steel 430 (UNS S43000) with $1.0 \mathrm{wt} \% \mathrm{Mn}(\max )$. The $\mathrm{MnCr}_{2} \mathrm{O}_{4}$ spinel has been reported ${ }^{24-26}$ on the outer scale for Crofer 22 APU after exposure in moist air at $800^{\circ} \mathrm{C}$.

Other mitigation techniques involve perovskite coatings such as $\mathrm{La}_{0.9} \mathrm{Sr}_{0.1} \mathrm{CrO}_{3}$ (LSC), $\mathrm{La}_{0.9} \mathrm{Ca}_{0.1} \mathrm{CrO}_{3}$ (LCaC), and $\mathrm{La}_{0.8} \mathrm{Sr}_{0.2} \mathrm{MnO}_{3}(\mathrm{LSM}) .{ }^{21,27}$ Some, like LSC and $\mathrm{LCaC}$ aim to reduce $\mathrm{Cr}$ evaporation by lowering the activity of $\mathrm{Cr}$ in the oxide. Others, like LSM, seek to eliminate $\mathrm{Cr}$ evaporation by removing it from the outer surface of the interconnect. However, even with LSM, Cr diffuses through the coating and subsequently can evaporate. ${ }^{21}$

\section{Supercritical Steam Turbine Environments}

Development of advanced steam turbines is underway in much of the world to improve the efficiency of power generation from coal. While much of the alloy development involves improving high temperature creep strength, steam oxidation resistance is also of importance. Current U.S. Department of Energy research programs are aimed at $60 \%$ efficiency from coal generation, which would require increasing the operating conditions to as high as $760^{\circ} \mathrm{C}$ and $37.9 \mathrm{MPa}(374 \mathrm{~atm})$ for the high pressure (HP) turbine. Current technology limits operation to about $620^{\circ} \mathrm{C}$. Research is also being directed at intermediate temperatures of 650,700 and $732^{\circ} \mathrm{C}$. Above $650^{\circ} \mathrm{C}$, it is expected that nickel-base alloys will be required based on creep strength limitations of ferritic and austenitic stainless steels.

Since candidate alloys for this application are all chromia formers, reactive evaporation could be an important degradation mechanism. Representative environments for current and advanced steam turbines were chosen as: temperatures of $540,600,680,720,740$, and $760^{\circ} \mathrm{C}$, pressures of $163,197,306$, and 340 $\mathrm{atm}$, steam velocity of $300 \mathrm{~m} / \mathrm{s}$ (calculated from $60 \mathrm{~Hz}, 3600$ revolutions per minute, and $0.8 \mathrm{~m}$ rotor + blade radius), and characteristic length of $0.05 \mathrm{~m}$. This is turbulent flow, so Eq. 9 was used. The values used for the partial pressure of oxygen were based off of oxygenated feedwater that is typical of once-through supercritical power plants, i.e., dissolved oxygen (DO) of 50 to $150 \mathrm{ppb}$ and a $\mathrm{pH}$ of 8.0-8.5 controlled with ammonia additions. ${ }^{14}$ By the time the feedwater enters the boiler, most of the DO has been removed to less than $1 \mathrm{ppb} .{ }^{28}$ However, at high temperatures, water undergoes dissociation to $\mathrm{O}_{2}$ and $\mathrm{H}_{2}$ to levels above 1 ppb. To estimate the DO at temperature and pressure, the program FactSage ${ }^{29}$ was used to first determine the amount of $\mathrm{NH}_{3}$ required for a $\mathrm{pH}$ of 8.25 at $25^{\circ} \mathrm{C}-34.5 \mathrm{ppb}$. This agreed well with the reported ${ }^{14} 20-65 \mathrm{ppb}$ $\mathrm{NH}_{3}$ used for $\mathrm{pH}$ control to 8.0 to 8.5. Next FactSage was used to find the value of $\mathrm{P}_{\mathrm{O} 2}$ for each temperature and pressure combination from water with $34.5 \mathrm{ppb} \mathrm{NH}_{3}$. A minimum of $1 \mathrm{ppb}$ of DO was used for cases where the dissociation pressure of $\mathrm{O}_{2}$ was less than $1 \mathrm{ppb}$. Output from FactSage included the fugacities of 
$\mathrm{H}_{2} \mathrm{O}$ and $\mathrm{O}_{2}$, so these were used in place of $\mathrm{P}_{\mathrm{H} 2 \mathrm{O}}$ and $\mathrm{P}_{\mathrm{O} 2}$ in Eq. 9. The use of fugacities made only a minor difference because the fugacity adjustments tended to cancel each other out in Eq. 9. Results are shown in Table 7 and Fig. 6.

These predicted rates are large compared to the experimental tests at atmospheric pressure and low gas velocities (Table 6). The highest value in Table 7 (for $760^{\circ} \mathrm{C}$ and $340 \mathrm{~atm}$ ) of $5.18 \times 10^{-8} \mathrm{~kg} / \mathrm{m}^{2} / \mathrm{s}$ is equivalent to $0.080 \mathrm{~mm}$ per year of solid $\mathrm{Cr}$ loss (assumes a metal density of $9 \mathrm{~g} / \mathrm{cm}^{3}$ and a conversion to a $\mathrm{Cr}$ basis in a manner similar to Eq. 18). This is a large value for metal loss for a component expected to operate many years, and it may be larger if the scale losses enough $\mathrm{Cr}$ to become non-protective. Current state-of-the-art steam turbines operate at approximately $600^{\circ} \mathrm{C}$ and $31 \mathrm{MPa}(306 \mathrm{~atm})$, with a predicted evaporation rate of $1.90 \times 10^{-9} \mathrm{~kg} / \mathrm{m}^{2} / \mathrm{s}$. Typical subcritical steam power plants operate at $538^{\circ} \mathrm{C}$ and 16.5 $\operatorname{MPa}(163 \mathrm{~atm})$, with a predicted evaporation rate of about $4.2 \times 10^{-10} \mathrm{~kg} / \mathrm{m}^{2} / \mathrm{s}$. These later two cases should have lower evaporation rates in practice because the ferritic-martensitic steels used usually form Fe-Cr spinel outer scales instead of chromia scales. This lowers the activity of chromia in the scale, which lowers the partial pressure of $\mathrm{CrO}_{2}(\mathrm{OH})_{2}(\mathrm{~g})$ (Eq. 17) and thus lower the evaporation rate.

In a recent review of the current understanding in steam oxidation in power plants, Saunders and McCartney ${ }^{30}$ consider and then reject $\mathrm{Cr}$ evaporation as an important oxidation mechanism (except for its possible role inside pores and fissures in Cr-migration). At $627^{\circ} \mathrm{C}, 440 \mathrm{ppb} \mathrm{DO}$ and $300 \mathrm{~atm}$, a $\mathrm{P}_{\mathrm{CrO} 2(\mathrm{OH}) 2}$ of about $10^{-11} \mathrm{~atm}$ was reported ${ }^{30}$ and was considered too small to be of importance. This value is much lower than is found using Eq. 17 and the Gibbs energy of formation data in Table 4, where values of $1.8 \times 10^{-8} \mathrm{~atm}$ (Glusko), $2.5 \times 10^{-7} \mathrm{~atm}$ (Gindorf), and $4.8 \times 10^{-6} \mathrm{~atm}$ (Glusko) are obtained. The evaporation methodology, using the Gindorf $\Delta \mathrm{G}_{\mathrm{f}, \mathrm{CrO} 2(\mathrm{OH}) 2}$, predicts an evaporation rate of $2.3 \times 10^{-7} \mathrm{~kg} / \mathrm{m}^{2} / \mathrm{s}$ (equivalent to about $0.34 \mathrm{~mm}$ per year of solid $\mathrm{Cr}$ ) for these conditions in a steam turbine. Note that these conditions probably assume a too large of a value of DO, which lead to quite high evaporation rate predictions. An estimate from Table 7, with a DO of $1 \mathrm{ppb}$, predicts about $2 \times 10^{-9} \mathrm{~kg} / \mathrm{m}^{2} / \mathrm{s}$ (equivalent to about $0.003 \mathrm{~mm} /$ year of solid $\mathrm{Cr}$ ). For the types of materials in current power plants (and the focus of Saunders and McCarney ${ }^{30}$ ), this evaporation rate would be even lower as the assumption of a pure $\mathrm{Cr}_{2} \mathrm{O}_{3}$ scale would not be met - and indeed may be of little importance. These materials include T22, P91, and P92 ferritic steels and 300-series austenitic steels. Scale thicknesses are much larger (i.e., $60-100 \mu \mathrm{m}$ at $600^{\circ} \mathrm{C}$ and $120-240 \mu \mathrm{m}$ at $650^{\circ} \mathrm{C}$ for $\mathrm{P} 92$ after 1000 hours ${ }^{30}$ ) for these materials than for the nickel base superalloys considered for higher temperatures (i.e., $\sim 1 \mu \mathrm{m}$ for Haynes 230 at $760^{\circ} \mathrm{C}$ in moist air for 2000 hourly cycles-Fig. $5 .^{21}$ ). Equation 4 shows that the eventual steady state scale thickness is related to the relative sizes of $\mathrm{k}_{\mathrm{p}}$ and $\mathrm{k}_{\mathrm{e}}$. So evaporation will be of much greater relative importance in describing oxidation mechanisms in nickel-base superalloys with slower growing chromia scales.

\section{Mitigation}

Mitigation of these predicted high evaporation rates can be speculated upon. One way could be to reduce the activity of $\mathrm{Cr}$ in the oxide scale in similar ways as used in SOFC interconnect development. However, other properties of the alloy would have to be maintained. For example, Mn alloy additions generally reduce high temperature creep strength in $9-12 \% \mathrm{Cr}$ ferritic alloys. ${ }^{31}$ The adherence of perovskite coatings is not established, and would need to be evaluated.

Turbine blade coatings might be effective. These could consist of either a coating to lower $\mathrm{Cr}$ oxide activity (as discussed with SOFC coatings) or a thermal barrier coating (TBC). Porous TBCs would in effect increase the width of the diffusion boundary layer and thus reduce the evaporation rate. When combined with internal blade cooling, a TBC would also decrease the surface temperature. This would reduce the evaporation rate and also reduce the overall oxidation rate. There is much experience with TBC in gas turbines, but these add significant expense in both capital and maintenance costs.

Finally, the presence of $\mathrm{Cr}$ evaporation taking place in the superheater tubes prior to the turbine may to some degree saturate the steam with $\mathrm{CrO}_{2}(\mathrm{OH})_{2}(\mathrm{~g})$, thereby reducing the driving force for evaporation. The lower steam velocity in the superheater tubes $\left(10-25 \mathrm{~m} / \mathrm{s}^{\text {s is typical }}{ }^{14}\right)$ will result in lower evaporation rates than in the steam turbine $(\sim 300 \mathrm{~m} / \mathrm{s})$, but there is considerable length of superheater tubing at the high 
temperature and pressure of the HP turbine that could allow a build up of $\mathrm{CrO}_{2}(\mathrm{OH})_{2}(\mathrm{~g})$. Evaporation in the superheater may move evaporation issues upstream and reduce them in the turbine.

\section{Laboratory Experimentation}

Laboratory corrosion tests generally seek to mimic the process environment as closely as possible. In cases where this is difficult, then one seeks to establish conditions where the corrosion mechanisms are the same. For steam turbines, laboratory tests with the same combination of temperature, pressure, gas velocities, and steam chemistry are extremely difficult and expensive. Therefore tests sacrifice one or more of the conditions - usually pressure and or gas velocity.

For examining the effects of Cr-evaporation as a corrosion mechanism, laboratory tests may be best served with much higher oxygen partial pressures so as to increase the evaporation rate. A comparison of the evaporation rates from Tables 6 and 7 show that even with air and water vapor mixtures, experimental tests (Table 6) fail to achieve the predicted evaporation rates at high pressures and gas flows (Table 7) by several orders of magnitude. As discussed earlier, for $\mathrm{O}_{2}+\mathrm{H}_{2} \mathrm{O}$ mixtures, a $\mathrm{P}_{\mathrm{H} 2 \mathrm{O}}$ equal to ${ }_{7}^{4} \mathrm{P}_{\mathrm{O} 2}\left(\sim 57 \% \mathrm{H}_{2} \mathrm{O}\right)$ should maximize the evaporation rate. The same holds true (albeit at a lower evaporation rate) for air $+\mathrm{H}_{2} \mathrm{O}$ mixtures with the maximum also at $57 \% \mathrm{H}_{2} \mathrm{O}$. Laboratory tests in steam at atmospheric pressure will have extremely small evaporation rates due to the low partial pressure of oxygen. This is all illustrated in Fig. 8 for predictions made at $760^{\circ} \mathrm{C}$. In Fig. 8 the advanced steam turbine points are from the A, B, and C data in Table 7 (point $\mathrm{C}$ at $760^{\circ} \mathrm{C}$ is the direct comparison, points $\mathrm{A}$ and $\mathrm{B}$ are at lower temperatures). The representative laboratory curves are as a function of the partial pressure of $\mathrm{O}_{2}$ in either $\mathrm{O}_{2}+\mathrm{H}_{2} \mathrm{O}$ or air $+\mathrm{H}_{2} \mathrm{O}$ atmospheres. The laboratory curves were all calculated at atmospheric pressure, $u=0.02 \mathrm{~m} / \mathrm{s}$ and $\mathrm{L}=0.02$ $\mathrm{m}$. The right-hand-side of the laboratory curves drop sharply as $\mathrm{P}_{\mathrm{H} 2 \mathrm{O}}$ approaches zero. The right-hand-side of the laboratory curves are limits. Reactive evaporation in drier $\mathrm{O}_{2}$ or drier air would switch at that point from $\mathrm{CrO}_{2}(\mathrm{OH})_{2}(\mathrm{~g})$ being the dominate gas specie to $\mathrm{CrO}_{3}(\mathrm{~g})$, and would not drop further with less $\mathrm{H}_{2} \mathrm{O}$.

Efforts to improve laboratory tests for higher evaporation rates would include testing in either $\mathrm{O}_{2}+\mathrm{H}_{2} \mathrm{O}$ or Air $+\mathrm{H}_{2} \mathrm{O}$ at $57 \% \mathrm{H}_{2} \mathrm{O}$, increasing the gas velocity $\left(\mathrm{k}_{\mathrm{e}}\right.$ is proportional to $\mathrm{u}^{1 / 2}$ ), increasing the sample size $\left(\mathrm{k}_{\mathrm{e}}\right.$ is proportional to $\left.\mathrm{L}^{1 / 2}\right)$, or increasing the total pressure (moving the reaction of Eq. 2 to the right).

\section{Conclusions}

A methodology was developed to calculate $\mathrm{Cr}$ evaporation rates from $\mathrm{Cr}_{2} \mathrm{O}_{3}$ with a flat planar geometry. As part of this calculation, the interdiffusion coefficient, absolute viscosity, and the Gibbs energy of reaction were determined. The major variables include temperature, total pressure, gas velocity, and gas composition. Experimental verification was done at atmospheric pressure in moist air and moist oxygen. It was concluded that the Gindorf ${ }^{21}$ data for $\Delta \mathrm{G}_{\mathrm{f}, \mathrm{CrO} 2(\mathrm{OH}) 2}$ gave a close match with observed evaporation rates, and so was used for further calculations.

The methodology was applied to SOFC conditions for metallic interconnects. Current mitigation techniques for reducing $\mathrm{Cr}$ poisoning of the SOFC with Mn additions to the alloy and perovskite coatings were discussed in terms of the methodology.

The methodology was also applied to advanced steam turbines conditions. The high velocities and pressures of the advanced steam turbine led to evaporation predictions as high as $5.18 \times 10^{-8} \mathrm{~kg} / \mathrm{m}^{2} / \mathrm{s}$ at $760^{\circ} \mathrm{C}$ and $34.5 \mathrm{MPa}$. This is equivalent to $0.080 \mathrm{~mm}$ per year of solid $\mathrm{Cr}$ loss. Should this Cr loss be too large to maintain sufficient $\mathrm{Cr}$ for a protective oxide scale, then much higher oxidation rates could result. Chromium evaporation is expected to be an important oxidation mechanism with the types of nickel-base alloys proposed for use above $650^{\circ} \mathrm{C}$ in advanced steam boilers and turbines. Chromium evaporation is of less importance for the ferritic and austenitic alloys used in current steam boilers and turbines due to their relatively large oxidation rates with respect to evaporation rates.

Possible mitigation techniques were discussed, including those used in SOFC metallic interconnects (adding Mn to the alloy and perovskite coatings), thermal barrier coatings (TBC) with or without internal cooling, and partial or full saturation of the steam with $\mathrm{CrO}_{2}(\mathrm{OH})_{2}(\mathrm{~g})$ from $\mathrm{Cr}$ evaporation in the superheater. Of these, Mn additions are limited by reductions in creep strength, and TBC by increased capital and 
maintenance costs. The partial or full saturation of the steam with $\mathrm{CrO}_{2}(\mathrm{OH})_{2}(\mathrm{~g})$ from Cr evaporation in the superheater may significantly reduce turbine blade evaporation, but also move evaporation issues upstream into the superheater.

It was shown that laboratory experiments, with much lower steam velocities and usually much lower total pressure than found in advanced steam turbines, would best reproduce chromium evaporation behavior with atmospheres that approach either $\mathrm{O}_{2}+\mathrm{H}_{2} \mathrm{O}$ or Air $+\mathrm{H}_{2} \mathrm{O}$ at $57 \% \mathrm{H}_{2} \mathrm{O}$ instead of with oxygenated steam.

\section{References}

1. K. Hilpert, D. Das, M. Miller, D. H. Peck, R. Weiß, Journal of the Electrochemical Society, Vol. 143, 1996, 143, pp. 3642-3647.

2. S. P. Jiang, J. P. Zhang, J. Föger, Journal of the Electrochemical Society, Vol. 147, 2000, pp. $3195-$ 3205 .

3. S. P. Jiang, J. P. Zhang, L. Apateanu, K. Föger, Journal of the Electrochemical Society, Vol. 147, 2000, pp. 4013-4022.

4. F. Chen, E. Sun, J. Yamanis, J. Hawkes, J. Smeggil, S. Warrier, J.-W. Kim, "Cr Poisoning Effect for Solid Oxide Fuel Cells," in Fuel Cells and Energy Storage Systems: Materials, Processing, Manufacturing and Power Management Technologies, proceedings of Materials Science and Technology (MS\&T) 2006: Materials and Systems, Vol. I, 2006, pp. 303-311.

5. H. Asteman, J.-E. Svensson, L.-G. Johansson, M. Norell, Oxidation of Metals, Vol. 52, 1999, pp. 95111.

6. H. Asteman, J.-E. Svensson, M. Norell, L.-G. Johansson, Oxidation of Metals, Vol. 54, 2000, pp. 11-26.

7. D. R. Gaskell, An Introduction to Transport Phenomena in Materials Engineering, New York (NY): Macmillan Publishing, 1992, pp. 78-89 (chapter 2) and 569-578 (chapter 11).

8. G. H. Geiger, D. R. Poirier, Transport Phenomena in Metallurgy, Reading (MA): Addison-Wesley Publishing, 1973, pp. 7-13 (chapter 1), 463-467 (chapter 13) and 529-537 (chapter 15).

9. W. A. Tucker, L. H. Nelken, "Diffusion Coefficients in Air and Water," Handbook of Chemical Property Estimation Methods, Eds. W. J. Lyman, W. F. Reehl, D. H. Rosenblatt, Washington DC: American Chemical Society, 1990, pp. 17.9-17.13.

10. E. N. Fuller, P. D. Schettler, J. C. Giddings, Industrial \& Engineering Chemistry, Vol. 58, 1966, pp. 1927.

11. S. Veliah, K.-H. Xiang, R. Pandey, J. M. Recio, J. M. Newsam, Journal of Physical Chemistry B, Vol. 102, 1988, pp. 1126-1135.

12. R. B. Bird, W. E. Stewart, E. D. Lightfoot, Transport Phenomena, New York (NY), John Wiley \& Sons, 1960, pp. 504-506 (chapter 16).

13. J. C. Slattery, R. B. Bird, American Institute of Chemical Engineers Journal, Vol. 4, 1958, pp. 137-142.

14. Steam, 40th ed., S. C. Stultz, J. B. Kitto, editors. Barberton (OH): Babcock \& Wilcox, 1992, pp. 3.8-3.9, 42-11. 
15. C. R. Wilke, Journal of Chemical Physics, Vol. 18, 1950, pp. 517-519.

16. E. J. Opila, Materials Science Forum, Vols. 461-464, 2004, pp. 765-774.

17. Glusko Thermocenter of the Russian Academy of Sciences-Izhorskaya 13/19, 127412, Moscow Russia: IVTAN Association; 1994.

18. B. B. Ebbinghaus, Combustion and Flame, Vol. 93, 1993, pp. 119-137.

19. V. S. Yungman, V. A. Medvedev, I. V. Veits, G. A. Bergman. IVTANTHERMO-A Thermodynamic Database and Software System for the Computer. Boca Raton FL: CRC Press and Begell House; 1993.

20. A. Roine, HSC Chemistry 5.11. Pori Finland: Outokumpu Research Oy; 2002.

21. C. Gindorf, K. Hilpert. L. Singheiser, "Determination of Chromium Vaporization Rates of Different Interconnect Alloys by Transpiration Experiments. H. Yokokawa, S. C. Singhal, editors, in Solid Oxide Fuel Cells (SOFC VII), Proceedings Vol. 2001-16, Pennington (NJ): Electrochemical Society, 2001, pp. 793-802.

22. G. R. Holcomb, M. Ziomek-Moroz, D. E. Alman, "Oxidation of Alloys for Advanced Steam Turbines," in Proceedings of the $23^{\text {rd }}$ Annual Pittsburgh Coal Conference, 2006.

23. G. R. Holcomb, D. E. Alman, Scripta Materialia, Vol. 54, 2006, pp. 1821-1825.

24. J. Hammer, S. Laney, W. Jackson, F. Pettit, G. Meier, "Fundamental Studies of the Durability of Materials for Interconnects in Solid Oxide Fuel Cells," in SECA Annual Workshop and Core Technology Program Peer Review, 2005.

25. Z. Yang, M. S. Walker, P. Singh, J. W. Stevenson, T. Norby, Journal of the Electrochemical Society, Vol. 151, 2004, pp. B669-B678.

26. J. W. Stevenson, Z. G. Yang, P. Singh, G. H. Meier, "Corrosion and Corrosion Processes in SOFC Power Generation Systems," in 1st International Conference on Fuel Cell Development and Deployment, Storrs (CT), 2004.

27. Y. Larring, T. Norby, Journal of the Electrochemical Society, Vol. 147, 2000, pp. 3251-3256.

28. S. C. Kung, private communication, The Babcock \& Wilcox Company, Barberton, OH, 2007.

29. C. W. Bale, A. D. Pelton, W. T. Thompson, G. Eriksson, K. Hack, P. Chartrand, S. Decterov, J. Melançon, S. Petersen, Factsage 5.5, Thermfact and GTT-Technologies, 2007.

30. S. R. J. Saunders, L. N. McCartney, Materials Science Forum, Vols. 522-523, 2006, pp. 119-128.

31. F. Masuyama, ISIJ International, Vol. 41, 2001, pp. 612-625. 
Table 1 - Molecular masses and diffusion volumes for a variety of gas species and mixtures

\begin{tabular}{lrrl}
\hline Specie/Mixture & $\mathrm{M}_{\mathrm{i}}(\mathrm{kg} / \mathrm{mol})$ & $\mathrm{v}_{\mathrm{i}}\left(\mathrm{m}^{3} / \mathrm{mol}\right)$ & Source \\
\hline $\mathrm{O}_{2}$ & 0.03200 & $1.66 \times 10^{-5}$ & Fuller et al. ${ }^{11}$ \\
$\mathrm{~N}_{2}$ & 0.02801 & $1.79 \times 10^{-5}$ & Fuller et al. ${ }^{11}$ \\
$\mathrm{H}_{2} \mathrm{O}$ & 0.01802 & $1.27 \times 10^{-5}$ & Fuller et al. ${ }^{11}$ \\
$\mathrm{Ar}$ & 0.03995 & $1.61 \times 10^{-5}$ & Fuller et al. ${ }^{11}$ \\
$\mathrm{CrO}_{2}(\mathrm{OH})_{2}$ & 0.11801 & $1.03 \times 10^{-5}$ & Sphere of radius $1.6 \times 10^{-10} \mathrm{~m}$ \\
$\mathrm{CrO}_{3}$ & 0.09999 & $1.03 \times 10^{-5}$ & Sphere of radius $1.6 \times 10^{-10} \mathrm{~m}$ \\
air & 0.02897 & $2.01 \times 10^{-5}$ & Fuller et al. ${ }^{11}$ \\
air $+3 \% \mathrm{H}_{2} \mathrm{O}$ & 0.02864 & $1.99 \times 10^{-5}$ & Weighted average of A and B \\
air $+50 \% \mathrm{H}_{2} \mathrm{O}$ & 0.02349 & $1.64 \times 10^{-5}$ & Weighted average of A and B \\
$\mathrm{Ar}+50 \% \mathrm{H}_{2} \mathrm{O}$ & 0.02898 & $1.44 \times 10^{-5}$ & Weighted average of A and B \\
\hline
\end{tabular}

Table 2 - Characteristic diameters

for viscosity. ${ }^{7-8}$

\begin{tabular}{lll}
\hline Specie & $\sigma(\mathrm{m})$ & $\varepsilon / \kappa_{\mathrm{B}}\left({ }^{\circ} \mathrm{K}\right)$ \\
\hline $\mathrm{O}_{2}$ & $3.433 \times 10^{-10}$ & 113 \\
$\mathrm{~N}_{2}$ & $3.681 \times 10^{-10}$ & 91.5 \\
$\mathrm{Ar}$ & $3.418 \times 10^{-10}$ & 124 \\
$\mathrm{Air}$ & $3.617 \times 10^{-10}$ & 97.0 \\
\hline
\end{tabular}

Table 3 - Collision integral values for viscosity. ${ }^{7-8}$

\begin{tabular}{rr|rr|rr|rr|rr|rr}
\hline$\kappa_{\mathrm{B}} \mathrm{T} / \varepsilon$ & $\Omega_{\eta}$ & $\kappa_{\mathrm{B}} \mathrm{T} / \varepsilon$ & $\Omega_{\eta}$ & $\kappa_{\mathrm{B}} \mathrm{T} / \varepsilon$ & $\Omega_{\eta}$ & $\kappa_{\mathrm{B}} \mathrm{T} / \varepsilon$ & $\Omega_{\eta}$ & $\kappa_{\mathrm{B}} \mathrm{T} / \varepsilon$ & $\Omega_{\eta}$ & $\kappa_{\mathrm{B}} \mathrm{T} / \varepsilon$ & $\Omega_{\eta}$ \\
\hline 0.30 & 2.785 & 1.00 & 1.587 & 1.70 & 1.248 & 2.8 & 1.058 & 4.2 & 0.9600 & 20 & 0.7432 \\
0.35 & 2.628 & 1.05 & 1.549 & 1.75 & 1.234 & 2.9 & 1.048 & 4.3 & 0.9553 & 30 & 0.7005 \\
0.40 & 2.492 & 1.10 & 1.514 & 1.80 & 1.221 & 3.0 & 1.039 & 4.4 & 0.9507 & 40 & 0.6718 \\
0.45 & 2.368 & 1.15 & 1.482 & 1.85 & 1.209 & 3.1 & 1.030 & 4.5 & 0.9464 & 50 & 0.6504 \\
0.50 & 2.257 & 1.20 & 1.452 & 1.90 & 1.197 & 3.2 & 1.022 & 4.6 & 0.9422 & 60 & 0.6335 \\
0.55 & 2.156 & 1.25 & 1.424 & 1.95 & 1.186 & 3.3 & 1.014 & 4.7 & 0.9382 & 70 & 0.6194 \\
0.60 & 2.065 & 1.30 & 1.399 & 2.0 & 1.175 & 3.4 & 1.007 & 4.8 & 0.9343 & 80 & 0.6076 \\
0.65 & 1.982 & 1.35 & 1.375 & 2.1 & 1.156 & 3.5 & 0.9999 & 4.9 & 0.9305 & 90 & 0.5973 \\
0.70 & 1.908 & 1.40 & 1.353 & 2.2 & 1.138 & 3.6 & 0.9932 & 5.0 & 0.9269 & 100 & 0.5882 \\
0.75 & 1.841 & 1.45 & 1.333 & 2.3 & 1.122 & 3.7 & 0.9870 & 6 & 0.8963 & 200 & 0.5320 \\
0.80 & 1.780 & 1.50 & 1.314 & 2.4 & 1.107 & 3.8 & 0.9811 & 7 & 0.8727 & 400 & 0.4811 \\
0.85 & 1.725 & 1.55 & 1.296 & 2.5 & 1.093 & 3.9 & 0.9755 & 8 & 0.8538 & & \\
0.90 & 1.675 & 1.60 & 1.279 & 2.6 & 1.081 & 4.0 & 0.9700 & 9 & 0.8379 & & \\
0.95 & 1.629 & 1.65 & 1.264 & 2.7 & 1.069 & 4.1 & 0.9649 & 10 & 0.8242 & & \\
\hline
\end{tabular}


Table 4 - Gibbs energy of formation for species of interest. Calculated from Roine ${ }^{20}$ unless otherwise indicated.

\begin{tabular}{|c|c|c|c|c|c|c|}
\hline $\mathrm{T}(\mathrm{K})$ & $\begin{array}{r}\Delta \mathrm{G}_{\mathrm{f}} \\
\mathrm{Cr}_{2} \mathrm{O}_{3}(\mathrm{~s}) \\
(\mathrm{J} / \mathrm{mol})\end{array}$ & $\begin{array}{r}\Delta \mathrm{G}_{\mathrm{f}} \\
\mathrm{H}_{2} \mathrm{O}(\mathrm{g}) \\
(\mathrm{J} / \mathrm{mol})\end{array}$ & $\begin{array}{r}\Delta \mathrm{G}_{\mathrm{f}} \\
\mathrm{CrO}_{3}(\mathrm{~g}) \\
(\mathrm{J} / \mathrm{mol})\end{array}$ & $\begin{array}{r}\Delta \mathrm{G}_{\mathrm{f}} \\
\mathrm{CrO}_{2}(\mathrm{OH})_{2}(\mathrm{~g}) \\
(\mathrm{J} / \mathrm{mol}) \\
(\mathrm{Glusko})^{17,20}\end{array}$ & $\begin{array}{r}\Delta \mathrm{G}_{\mathrm{f}} \\
\mathrm{CrO}_{2}(\mathrm{OH})_{2}(\mathrm{~g}) \\
(\mathrm{J} / \mathrm{mol}) \\
(\text { Gindorf })^{21}\end{array}$ & $\begin{array}{r}\Delta \mathrm{G}_{\mathrm{f}} \\
\mathrm{CrO}_{2}(\mathrm{OH})_{2}(\mathrm{~g}) \\
(\mathrm{J} / \mathrm{mol}) \\
\text { (Ebbinghaus) }^{18}\end{array}$ \\
\hline 500 & $-998,700$ & $-219,100$ & $-292,200$ & $-616,600$ & $-632,100$ & $-644,700$ \\
\hline 573 & $-979,300$ & $-215,400$ & $-287,400$ & $-599,000$ & $-615,100$ & $-629,500$ \\
\hline 600 & $-972,300$ & $-214,000$ & $-285,700$ & $-592,500$ & $-608,900$ & $-624,000$ \\
\hline 673 & $-954,300$ & $-210,300$ & $-280,900$ & $-574,900$ & $-592,500$ & $-608,900$ \\
\hline 700 & $-947,400$ & $-208,900$ & $-279,200$ & $-568,400$ & $-586,300$ & $-603,400$ \\
\hline 773 & $-928,700$ & $-205,000$ & $-274,400$ & $-550,900$ & $-569,400$ & $-588,300$ \\
\hline 800 & $-921,800$ & $-203,600$ & $-272,600$ & $-544,400$ & $-563,300$ & $-582,800$ \\
\hline 873 & $-903,300$ & $-199,700$ & $-267,800$ & $-526,900$ & $-546,400$ & $-567,700$ \\
\hline 900 & $-896,500$ & $-198,200$ & $-266,100$ & $-520,500$ & $-540,200$ & $-562,200$ \\
\hline 973 & $-878,100$ & $-194,200$ & $-261,200$ & $-503,000$ & $-523,400$ & $-547,200$ \\
\hline 1000 & $-871,300$ & $-192,700$ & $-259,500$ & $-496,500$ & $-517,200$ & $-541,700$ \\
\hline
\end{tabular}

Table 5 - Alloy compositions as found by x-ray florescence (XRF) for the nickel alloys or by the nominal composition for 304L stainless steel.

\begin{tabular}{ccccccccccccc}
\hline Alloy & Type & $\mathrm{Fe}$ & $\mathrm{Cr}$ & $\mathrm{Ni}$ & $\mathrm{Mo}$ & $\mathrm{W}$ & $\mathrm{Nb}$ & $\mathrm{Mn}$ & $\mathrm{Si}$ & $\mathrm{Cu}$ & $\mathrm{Al}$ & Other \\
\hline Haynes 230 & $\mathrm{XRF}$ & 1.3 & 22.6 & 58.8 & 1.3 & 14.3 & & 0.5 & 0.3 & 0.04 & 0.4 & \\
\hline Inconel 625 & XRF & 4.4 & 21.4 & 61.0 & 8.4 & & 3.4 & 0.1 & 0.4 & 0.3 & 0.2 & $0.3 \mathrm{Ti}$ \\
& & & & & & & & & & & & $0.01 \mathrm{~V}$ \\
& & & & & & & & & & & & $0.07 \mathrm{Co}$ \\
\hline 304L & Nom & Bal & 19.0 & 10.0 & & & & & & & & \\
\hline
\end{tabular}


Table 6 - Comparison of experimental and predicted evaporation rates (all on a $\mathrm{Cr}_{2} \mathrm{O}_{3}$ basis).

\begin{tabular}{|c|c|c|c|c|}
\hline $\begin{array}{c}\text { Alloy } \\
\text { and } \\
\text { Conditions }\end{array}$ & $\begin{array}{l}\text { Experimental } \\
\text { Slope } \\
\left(\mathrm{kg} \mathrm{m}^{-2} \mathrm{~s}^{-1}\right)\end{array}$ & $\begin{array}{c}\text { Evaporation based } \\
\text { on Glusko }{ }^{17} \\
\mathrm{CrO}_{2}(\mathrm{OH})_{2}(\mathrm{~g}) \\
\text { data }\left(\mathrm{kg} \mathrm{m}^{-2} \mathrm{~s}^{-1}\right)\end{array}$ & $\begin{array}{c}\text { Evaporation based } \\
\text { on Gindorf }{ }^{21} \\
\mathrm{CrO}_{2}(\mathrm{OH})_{2}(\mathrm{~g}) \\
\text { data }\left(\mathrm{kg} \mathrm{m}^{-2} \mathrm{~s}^{-1}\right)\end{array}$ & $\begin{array}{l}\text { Evaporation based } \\
\text { on Ebbinghaus }{ }^{18} \\
\mathrm{CrO}_{2}(\mathrm{OH})_{2}(\mathrm{~g}) \text { data } \\
\left(\mathrm{kg} \mathrm{m}^{-2} \mathrm{~s}^{-1}\right)\end{array}$ \\
\hline $\begin{array}{c}\text { Haynes } 230 \\
\text { UNS NO6230 } \\
760^{\circ} \mathrm{C} \\
38 \% \mathrm{H}_{2} \mathrm{O} \text { in air } \\
1.9 \times 10^{-3} \mathrm{~m} / \mathrm{s}\end{array}$ & $-3.46 \times 10^{-10(22)}$ & $-6.50 \times 10^{-11}$ & $-7.00 \times 10^{-10}$ & $-1.38 \times 10^{-08}$ \\
\hline $\begin{array}{c}\text { Haynes } 230 \\
\text { UNS NO6230 } \\
760^{\circ} \mathrm{C} \\
37 \% \mathrm{H}_{2} \mathrm{O} \text { in air } \\
7.6 \times 10^{-3} \mathrm{~m} / \mathrm{s}\end{array}$ & $-1.11 \times 10^{-9(22)}$ & $-1.27 \times 10^{-10}$ & $-1.37 \times 10^{-9}$ & $-2.69 \times 10^{-08}$ \\
\hline $\begin{array}{c}\text { Inconel } 625 \\
\text { UNS NO6625 } \\
760^{\circ} \mathrm{C} \\
37 \% \mathrm{H}_{2} \mathrm{O} \text { in air } \\
1.9 \times 10^{-3} \mathrm{~m} / \mathrm{s}\end{array}$ & $-4.13 \times 10^{-10}$ & $-6.50 \times 10^{-11}$ & $-7.00 \times 10^{-10}$ & $-1.38 \times 10^{-08}$ \\
\hline $\begin{array}{c}304 \mathrm{~L} \\
\mathrm{UNS} \mathrm{S} 30403 \\
600^{\circ} \mathrm{C} \\
10 \% \mathrm{H}_{2} \mathrm{O} \text { in } \mathrm{O}_{2} \\
2.5 \times 10^{-2} \mathrm{~m} / \mathrm{s}\end{array}$ & $-5.68 \times 10^{-10(6)}$ & $-3.79 \times 10^{-11}$ & $-5.23 \times 10^{-10}$ & $-1.03 \times 10^{-08}$ \\
\hline
\end{tabular}


Table 7 - Predicted partial pressures of $\mathrm{CrO}_{2}(\mathrm{OH})_{2}$ and evaporation rates in supercritical steam turbine conditions with DO set by the greater of the dissociation of water or $1 \mathrm{ppb}, \mathrm{u}$ of $300 \mathrm{~m} / \mathrm{s}$ and $\mathrm{L}$ of 0.05 $\mathrm{m}$. The $\mathrm{A}, \mathrm{B}$, and $\mathrm{C}$ designations refer to Figs. 6-7, where $\mathrm{A}$ is typical for conditions in current power plants, $\mathrm{B}$ is for current advanced power plants, and $\mathrm{C}$ is the DOE target conditions.

\begin{tabular}{|c|c|c|c|c|c|c|c|c|c|c|}
\hline $\begin{array}{l}\mathrm{T}, \\
{ }^{\circ} \mathrm{C}\end{array}$ & $\begin{array}{l}\mathrm{P}_{\mathrm{T}}, \\
\mathrm{atm}\end{array}$ & $\begin{array}{l}\mathrm{DO}, \\
\mathrm{ppb}\end{array}$ & $\begin{array}{r}\mathrm{O}_{2} \\
\text { fugacity } \\
\text { coe. }\end{array}$ & $\begin{array}{r}\mathrm{H}_{2} \mathrm{O} \\
\text { fugacity } \\
\text { coe. }\end{array}$ & $\begin{array}{r}\mathrm{P}_{\mathrm{CrO} 2(\mathrm{OH}) 2} \\
\mathrm{~atm}\end{array}$ & $\begin{array}{r}\mathrm{k}_{\mathrm{e}}, \\
\mathrm{kg} / \mathrm{m}^{2} / \mathrm{s}\end{array}$ & $\begin{array}{c}\mathrm{PD} \\
-(\mathrm{PD})^{\mathrm{o}} \\
\end{array}$ & $\mathrm{Re}$ & $\mathrm{Sc}$ & \\
\hline 540 & 163 & 1 & 1.136 & 0.892 & $3.70 \mathrm{E}-10$ & $4.17 \mathrm{E}-10$ & 0.790 & $2.2 \mathrm{E}+07$ & 0.93 & A \\
\hline 540 & 197 & 1 & 1.167 & 0.871 & $5.13 \mathrm{E}-10$ & $5.47 \mathrm{E}-10$ & 0.770 & $2.6 \mathrm{E}+07$ & 0.95 & \\
\hline 540 & 306 & 1 & 1.270 & 0.807 & 1.09E-09 & $9.56 \mathrm{E}-10$ & 0.650 & $4.1 \mathrm{E}+07$ & 1.13 & \\
\hline 540 & 340 & 1 & 1.304 & 0.788 & $1.31 \mathrm{E}-09$ & $1.11 \mathrm{E}-09$ & 0.640 & $4.5 \mathrm{E}+07$ & 1.14 & \\
\hline 600 & 163 & 1 & 1.118 & 0.917 & $7.10 \mathrm{E}-10$ & $7.80 \mathrm{E}-10$ & 0.840 & $1.9 \mathrm{E}+07$ & 0.89 & \\
\hline 600 & 197 & 1 & 1.145 & 0.901 & $9.76 \mathrm{E}-10$ & $1.02 \mathrm{E}-09$ & 0.810 & $2.3 \mathrm{E}+07$ & 0.92 & \\
\hline 600 & 306 & 1 & 1.233 & 0.850 & $2.11 \mathrm{E}-09$ & $1.90 \mathrm{E}-09$ & 0.740 & $3.5 \mathrm{E}+07$ & 1.01 & B \\
\hline 600 & 340 & 1 & 1.263 & 0.835 & 2.63E-09 & $2.21 \mathrm{E}-09$ & 0.730 & $3.9 \mathrm{E}+07$ & 1.02 & \\
\hline 680 & 163 & 1 & 1.101 & 0.942 & $1.45 \mathrm{E}-09$ & $1.55 \mathrm{E}-09$ & 0.880 & $1.6 \mathrm{E}+07$ & 0.86 & \\
\hline 680 & 197 & 1 & 1.124 & 0.930 & 2.02E-09 & $2.04 \mathrm{E}-09$ & 0.850 & $1.9 \mathrm{E}+07$ & 0.89 & \\
\hline 680 & 306 & 1 & 1.198 & 0.893 & 4.41E-09 & $3.95 \mathrm{E}-09$ & 0.810 & $3.0 \mathrm{E}+07$ & 0.94 & \\
\hline 680 & 340 & 1 & 1.223 & 0.882 & $5.31 \mathrm{E}-09$ & $4.62 \mathrm{E}-09$ & 0.800 & $3.3 \mathrm{E}+07$ & 0.95 & \\
\hline 720 & 163 & 4.94 & 1.094 & 0.951 & 6.59E-09 & $6.96 \mathrm{E}-09$ & 0.900 & $1.5 \mathrm{E}+07$ & 0.85 & \\
\hline 720 & 197 & 3.95 & 1.115 & 0.941 & 7.79E-09 & $7.86 \mathrm{E}-09$ & 0.890 & $1.8 \mathrm{E}+07$ & 0.86 & \\
\hline 720 & 306 & 2.12 & 1.184 & 0.910 & $1.07 \mathrm{E}-08$ & $9.63 \mathrm{E}-09$ & 0.855 & $2.7 \mathrm{E}+07$ & 0.90 & \\
\hline 720 & 340 & 1.78 & 1.207 & 0.901 & $1.13 \mathrm{E}-08$ & $9.87 \mathrm{E}-09$ & 0.845 & $3.0 \mathrm{E}+07$ & 0.91 & \\
\hline 740 & 163 & 11.26 & 1.091 & 0.955 & $1.42 \mathrm{E}-08$ & $1.48 \mathrm{E}-08$ & 0.905 & $1.4 \mathrm{E}+07$ & 0.85 & \\
\hline 740 & 197 & 9.39 & 1.112 & 0.946 & $1.73 \mathrm{E}-08$ & $1.74 \mathrm{E}-08$ & 0.900 & $1.7 \mathrm{E}+07$ & 0.86 & \\
\hline 740 & 306 & 5.65 & 1.178 & 0.918 & $2.59 \mathrm{E}-08$ & 2.32E-08 & 0.865 & $2.6 \mathrm{E}+07$ & 0.89 & \\
\hline 740 & 340 & 4.87 & 1.200 & 0.909 & $2.80 \mathrm{E}-08$ & $2.43 \mathrm{E}-08$ & 0.855 & $2.9 \mathrm{E}+07$ & 0.90 & \\
\hline 760 & 163 & 21.70 & 1.089 & 0.959 & $2.68 \mathrm{E}-08$ & $2.80 \mathrm{E}-08$ & 0.925 & $1.3 \mathrm{E}+07$ & 0.84 & \\
\hline 760 & 197 & 18.67 & 1.108 & 0.951 & $3.35 \mathrm{E}-08$ & $3.34 \mathrm{E}-08$ & 0.915 & $1.6 \mathrm{E}+07$ & 0.85 & \\
\hline 760 & 306 & 12.35 & 1.173 & 0.925 & 5.39E-08 & $4.82 \mathrm{E}-08$ & 0.885 & $2.5 \mathrm{E}+07$ & 0.88 & \\
\hline 760 & 340 & 10.94 & 1.194 & 0.917 & $5.95 \mathrm{E}-08$ & $5.18 \mathrm{E}-08$ & 0.880 & $2.8 \mathrm{E}+07$ & 0.88 & $\mathrm{C}$ \\
\hline
\end{tabular}




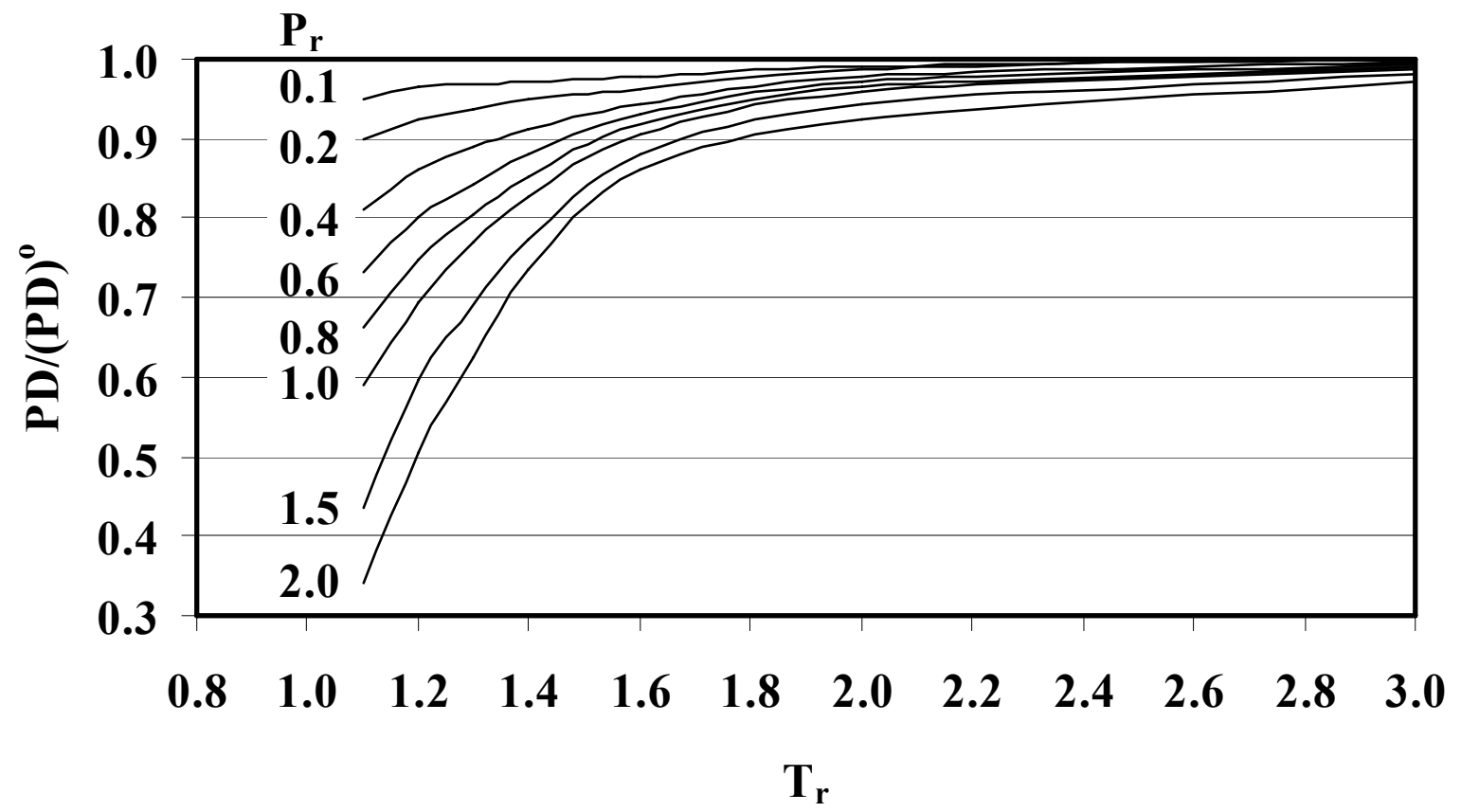

Fig. 1. Reduction of $\mathrm{D}$ for dense gases. $\mathrm{PD} /(\mathrm{PD})^{\circ}$ is the ratio of the pressure-diffusivity product at pressure $\mathrm{P}$ to the pressure-diffusivity product at atmospheric pressure (both at the same $\mathrm{T}$ ). $\mathrm{T}_{\mathrm{r}}$ and $\mathrm{P}_{\mathrm{r}}$ are the reduced temperature and pressure and are equal to $\mathrm{T} / \mathrm{T}_{\text {critical }}$ and $\mathrm{P} / \mathrm{P}_{\text {critical. }}$. Derived from Slattery and Bird. $^{12-13}$ 


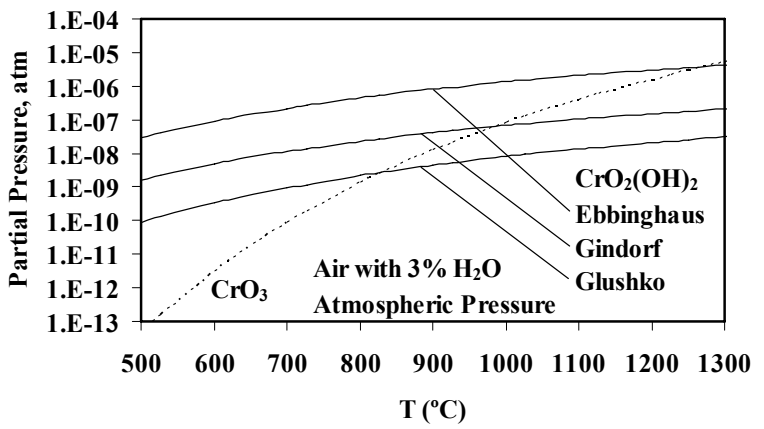

a)

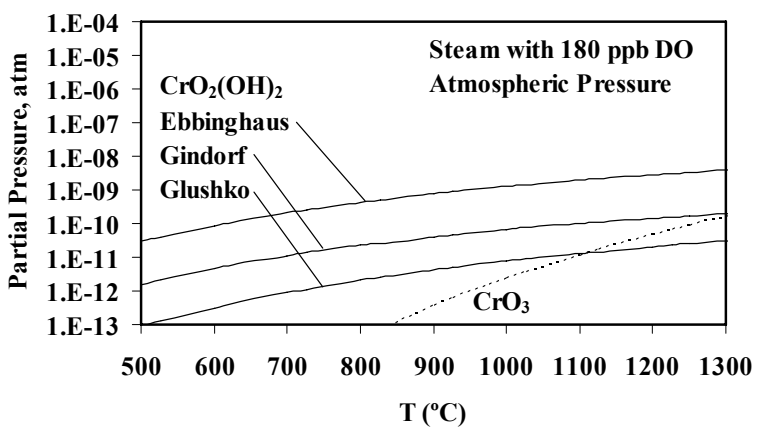

b)

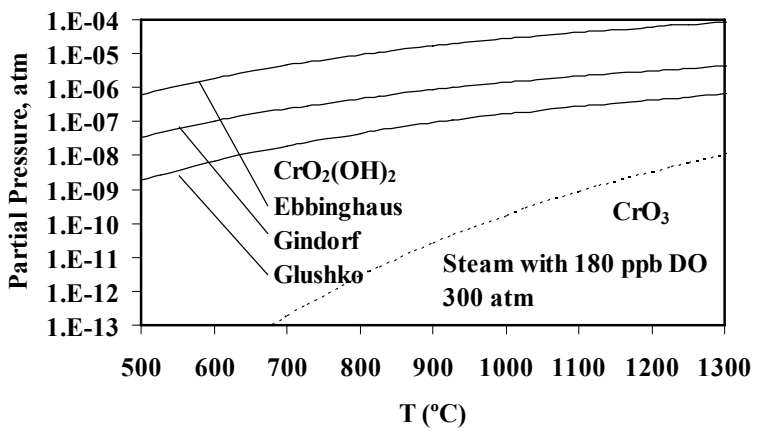

c)

Fig. 2. Partial pressures of $\mathrm{CrO}_{3}(\mathrm{~g})$ and $\mathrm{CrO}_{2}(\mathrm{OH})_{2}(\mathrm{~g})$ over pure $\mathrm{Cr}_{2} \mathrm{O}_{3}$ (activity of 1 ) for a) $3 \% \mathrm{H}_{2} \mathrm{O}$ in air at atmospheric pressure, b) steam with $180 \mathrm{ppb} \mathrm{DO}$ at atmospheric pressure, and c) steam with $180 \mathrm{ppb}$ DO at $300 \mathrm{~atm}$. 


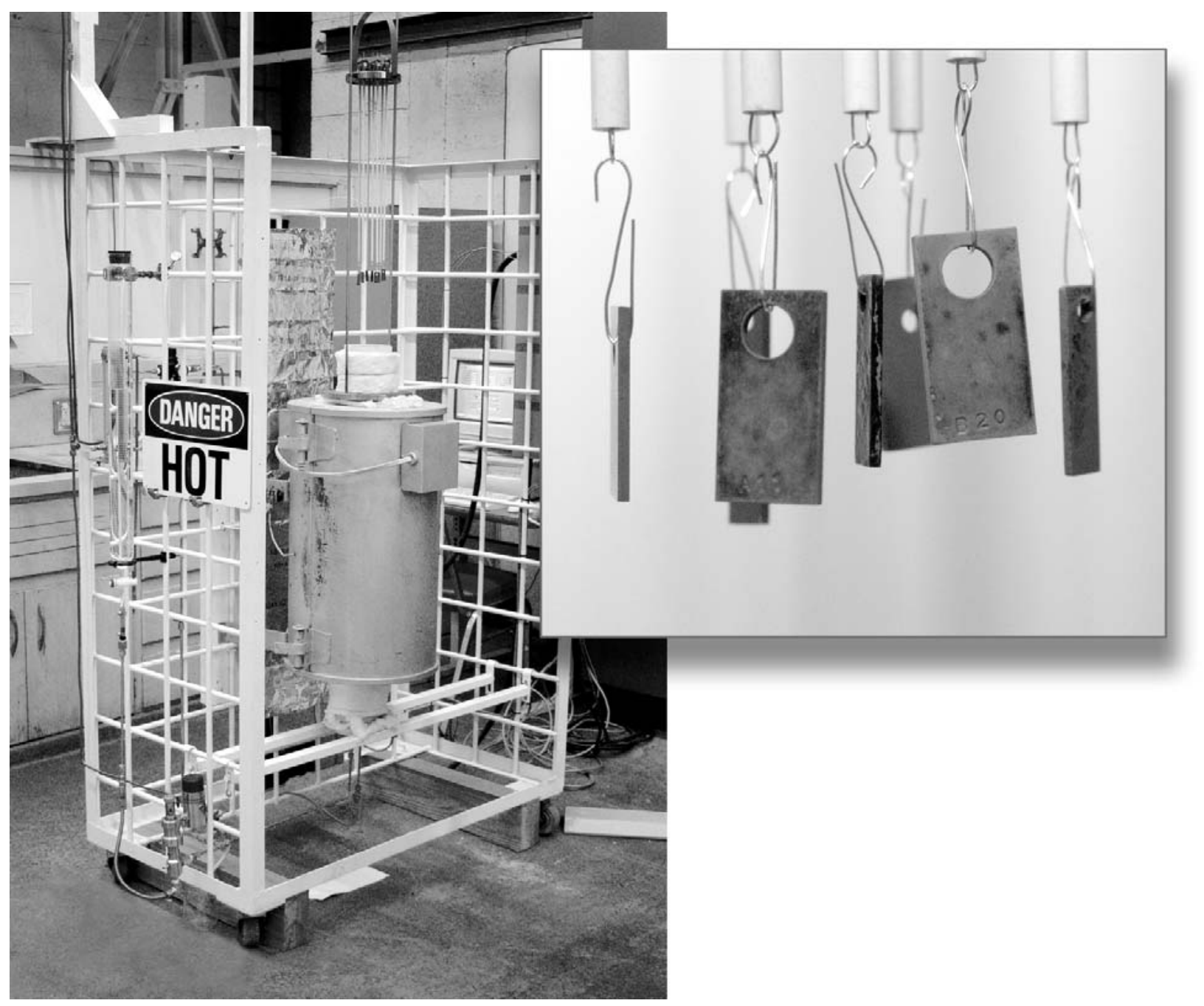

Fig. 3. Cyclic oxidation apparatus for testing in atmospheric pressure steam/air mixtures. 

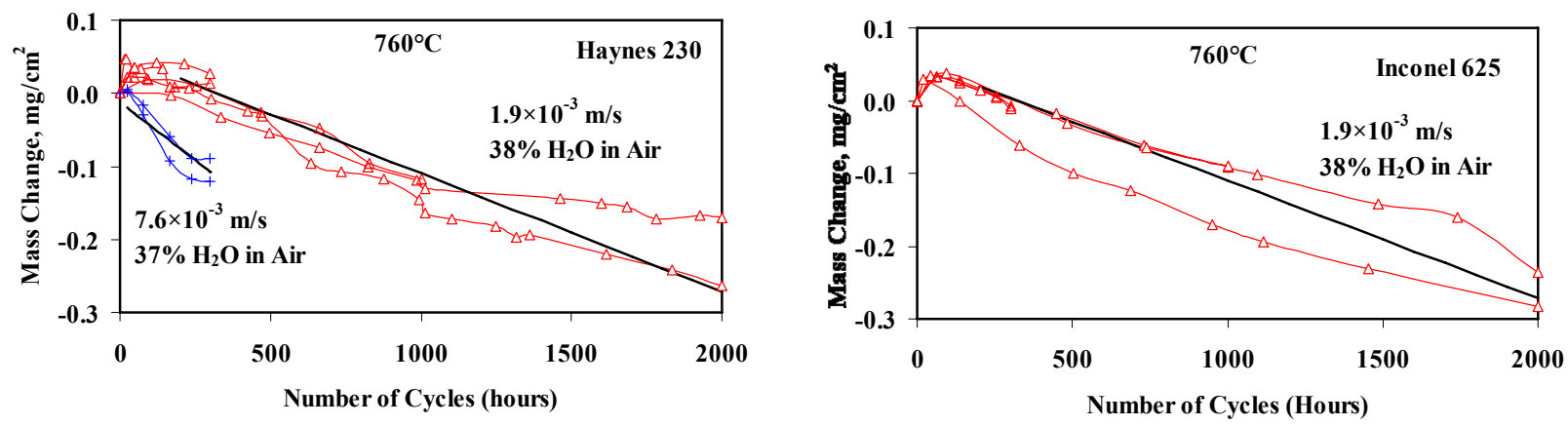

Fig. 4. Cyclic oxidation of Haynes 230 (UNS NO6230) ${ }^{22}$ and Inconel 625 (UNS NO6625) at $760^{\circ} \mathrm{C}$ in moist air. Triangle data points for $1.9 \times 10^{-3} \mathrm{~m} / \mathrm{s}$ and plus data points for $7.6 \times 10^{-4} \mathrm{~m} / \mathrm{s}$. Straight solid lines are the predicted slopes (on a $\mathrm{Cr}_{2} \mathrm{O}_{3}$ basis) from reactive evaporation of $\mathrm{Cr}_{2} \mathrm{O}_{3}$ (s) to $\mathrm{CrO}_{2}(\mathrm{OH})_{2}(\mathrm{~g})$ using the Gindorf ${ }^{21}$ data for $\mathrm{CrO}_{2}(\mathrm{OH})_{2}(\mathrm{~g})$. 


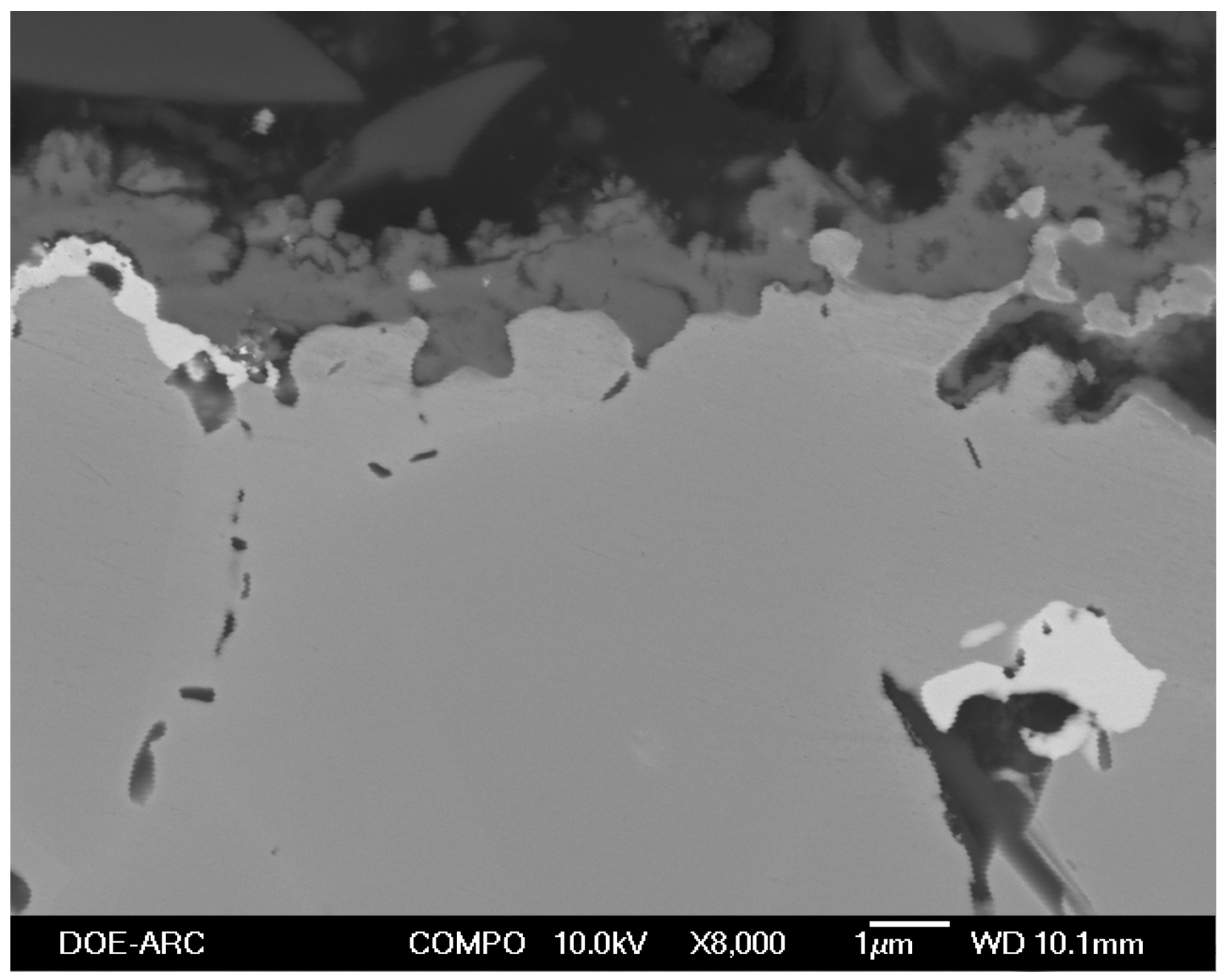

Fig. 5. Micrograph using backscattered electrons of Haynes 230 (UNS NO6230) after exposure at $760^{\circ} \mathrm{C}$ in moist air for 2000 cycles. ${ }^{22}$ The scale is predominately $\mathrm{Cr}_{2} \mathrm{O}_{3}$. The bright second phase is $\mathrm{W}$-rich. 


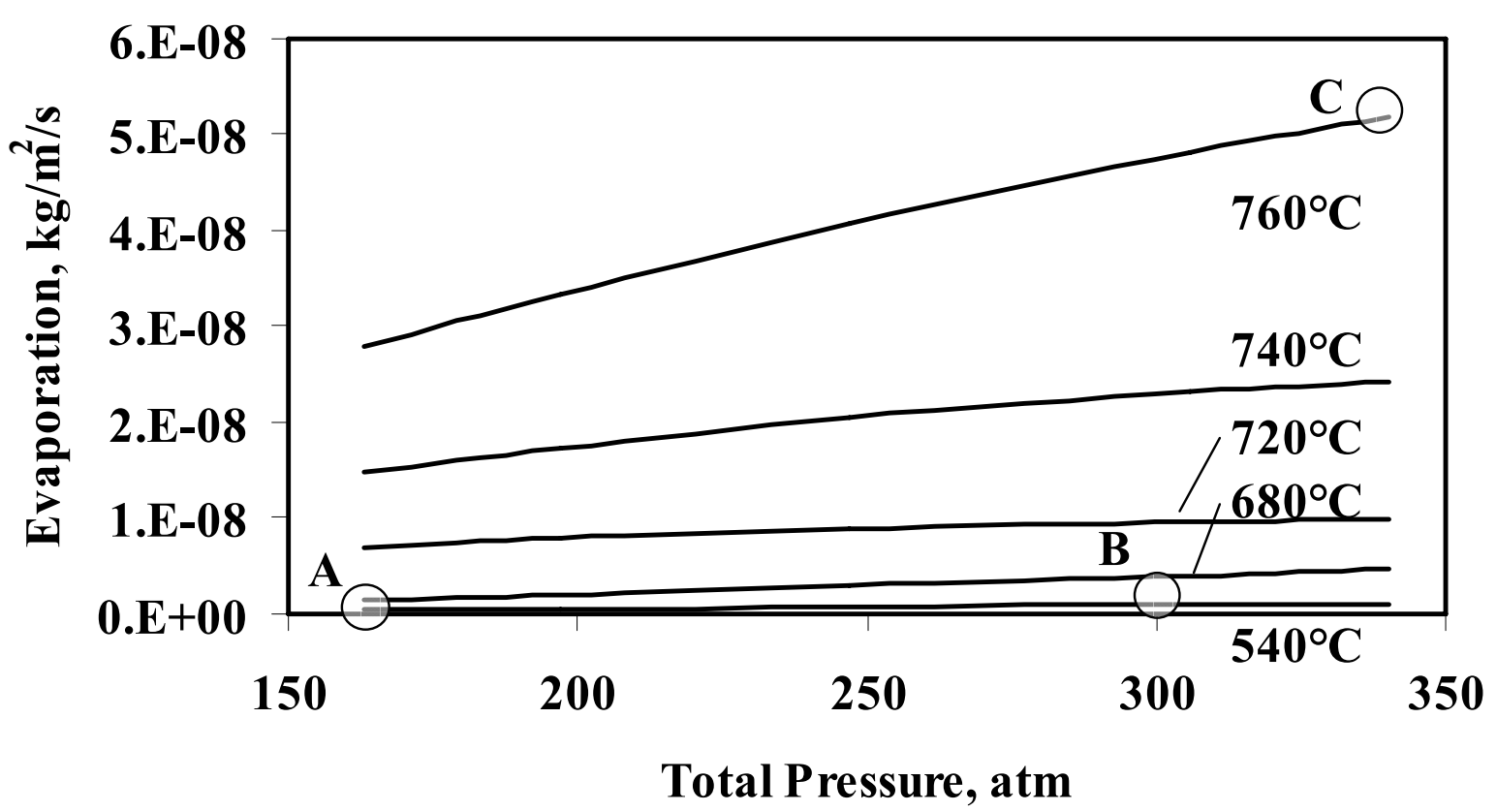

Fig. 6. Predicted evaporation rates in supercritical steam turbine conditions with DO set by the greater of the dissociation of water or $1 \mathrm{ppb}, 300 \mathrm{~m} / \mathrm{s}$ flow rate, and a characteristic length of $0.05 \mathrm{~m}$. Region " $\mathrm{A}$ " is typical for conditions in current power plants, " $\mathrm{B}$ " is for current advanced power plants, and " $\mathrm{C}$ " is the DOE target conditions (see Table 7). 


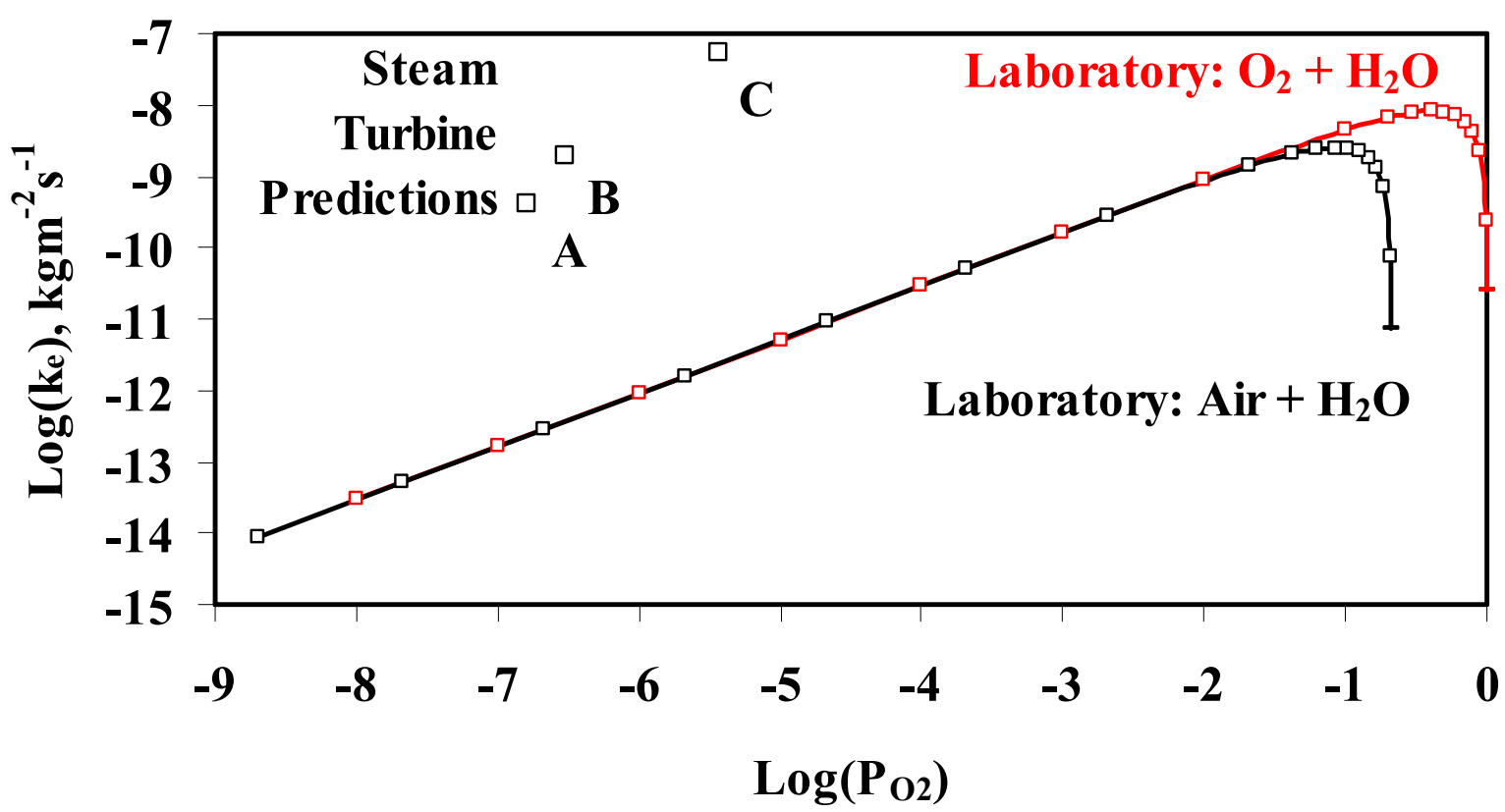

Fig. 7. Predicted evaporation rates for steam turbines (A, B, and $\mathrm{C})$ compared with atmospheric pressure laboratory tests $\left(760^{\circ} \mathrm{C}, \mathrm{u}=0.02 \mathrm{~m} / \mathrm{s}, \mathrm{L}=0.02 \mathrm{~m}\right)$ as a function of the partial pressure of $\mathrm{O}_{2}$ for tests in either $\mathrm{O}_{2}+\mathrm{H}_{2} \mathrm{O}$ or Air $+\mathrm{H}_{2} \mathrm{O}$. " $\mathrm{A}$ " is typical for conditions in current power plants, " $\mathrm{B}$ " is for current advanced power plants, and "C" is the DOE target conditions (see Table 7). 